\title{
남조류에서 발생하는 독소의 문제점과 대책 An Overview of Problems Cyanotoxins Produced by Cyanobacteria and the Solutions Thereby
}

\author{
전봉석 · 한지선 · 김석구* · 안재환* 오혜철* - 박호동 ${ }^{\dagger}$ \\ Bong-seok Jeon · Jisun Han · Seog-Ku Kim* \\ Jae-Hwan Ahn* $\cdot$ Hye-Cheol Oh* $\cdot$ Ho-Dong Park ${ }^{\dagger}$ \\ 신슈대학교 이학부 물질순환학 코스 \\ *한국건설기술연구원 환경·플랜트연구소 \\ Department of Environmental Sciences, Faculty of Science, Shinshu University \\ *Environmental and Plant Engineering Research Institute, \\ Korea Institute of Civil Engineering and Building Technology
}

(Received November 29, 2015; Revised December 11, 2015; Accepted December 15, 2015)

\begin{abstract}
Cyanobacteria frequently dominate the freshwater phytoplankton community in eutrophic waters. Cyanotoxins can be classified according to toxicity as neurotoxin (Anatoxin-a, Anatoxin-a(s), Saxitoxins) or hepatotoxin (microcystins, nodularin, cylindrospermopsin). Microcystins are present within cyanobacterial cells generally, and they are extracted by the damage of cell membrane. It has been reported that cyanotoxins caused adverse effects and they are acculmulated in aquatic oganisms of lake, river and ocean. In natural, microcystins are removed by biodegradation of microorganisms and/or feeding of predators. However, in process of water treatment, the use of copper sulfate to remove algal cells caused extraction of a mess of microcystins. Microcysitns are removed by physical, chemical and biological methods according to reports. The reduction of nutrients $(\mathrm{N}$ and $\mathrm{P})$ inflow is basic method of prevention of cyanobacteria bloom formation. However, it is less effective than investigation because nutrients already present in the eutrophic lake. In natural lake, cyanobacteria bloom are not formed because macrophytes invade from coastal lake by eutrophication. Therefore, a coastal lake has to recover to prevent of cyanobacteria bloom formation.
\end{abstract}

Key Words : Cyanobacteria Bloom, Eutrophic Lake, Cyanotoxin, Microcystin

요약 : 녹조현상을 형성하는 유독남조류는 세계 각지의 부영양화 호수에서 장기간 관찰되고 있다. 남조에 의해 생산되는 독소 는 크게 신경독(anatoxin-a, anatoxin-a(s), saxitoxin)과 간독(microcystin, nodularin, cylindrospermopsin)으로 나뉜다. Microcystin 은 남조세포내에 존재하며, 세포막이 손상되면 외부로 방출된다고 사료되며, 용출된 microcystin은 생물에 악영향을 끼치며, 호수, 하천 및 해양의 수생생물에 microcystin이 축적된다고 알려져 있다. 자연계에서는 포식자에 의한 남조세포의 섭식 또는 남조세포로부터 용출된 microcystin의 미생물에 의한 분해에 의해 microcystin의 제거가 가능하지만, 정수처리 과정에서는 microcystin을 분해하는 미생물이 존재하지 않으므로, 세포제거를 위해 황산구리를 사용할 경우 대량의 microcystin이 용출되 므로 주의가 필요하다. 지금까지의 보고에 의하면 세포 밖으로 용출된 micorcystin을 제거하는 기술은 물리, 화학 및 생물학 적 방법이 있다. 녹조현상의 방지는 그 발생의 원인인 호수 외로부터 유입되는 영양염류인 질소와 인의 감소가 기본이지만, 부영양호의 경우 이미 유입된 영양염류를 축적하고 있으므로 투자에 비해 효과는 높지 않다. 호수가 본래의 상태일 때 부영 양화 된다면, 호수의 연안부에 수생식물의 침입이 일어나고, 식물플랑크톤에 의한 조류 번무 현상은 보이지 않는 것이 보통이 다. 이러한 관점으로 녹조현상 발생방지를 위해서는 일단 호수 연안을 정상적인 상태로 복원할 필요가 있다.

주제어 : 녹조현상, 부영양호, 남조류 독소, Microcystin

\section{1. 서 론}

2014년 여름 미국 오하이오 주 북부, 5대호 중 하나인 Lake Erie의 서쪽에 인접한 Toledo에서 약 50 만 명의 시민에 대해 음용, 요리 및 목욕 등에 있어 수돗물의 사용을 금지했다. Lake Erie에서는 2011년부터 거의 매년 여름 독성 조류의 이상발생이 보고되어 왔다. 2011년부터 계속된 비상사태인 녹조현상의 발생 원인으로 인구증가 및 농법, 수온 이외에도 기후변동의 영향이 지적된다. 이 후에는 세계각지의 담수역 에서의 남조류의 대량발생이 종래를 상회할 우려가 있다.
녹조현상을 형성하는 남조류 중 일부는 동물에 대해 간독, 신경독, 사람에 대해 피부독, 미생물에 대해 세포독으로 작 용하는 여러 종류의 독소를 단독 또는 복수 함유하고 있으 며, 외국 여러 나라에서는 예전부터 남조로 인한 가축이나 야생동물의 폐사가 보고되었다. ${ }^{1,2)}$ 일본 호수에서는 주로 간 독(Microcystin, 이하 $\mathrm{MC}$ )이 검출된다. 이외에도 드물지만 신경독인 Anatoxin-a와 후쿠이현 미카타호(Lake Mikata, Fukui, Japan)에서 분리된 Umezakia natans가 생산하는 간장, 신장, 비장의 괴사를 일으키는 Cylindrospermopsin이 있다 (Fig. 1). ${ }^{3)}$ 


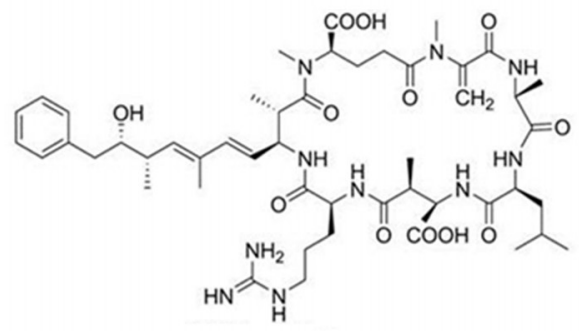

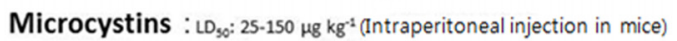
Producing cyanobacteria : Microcystis aeruginosa, M. viridis, Anabaenaflos-aquae, A. circinalis, Planktothrix agardhil, P. isothrix, Oscillatoria limosa, Aphanizomenon ovalisporum, Anabaenopsis millerii, Nostoc, Aphanocapsa spp., Cylindrospermopsis raciborskil, etc.

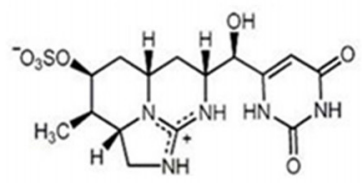

\section{Cylindrospermopsin:}

$\mathrm{LO}_{\mathrm{so}}: 300-2100 \mu \mathrm{g} \mathrm{kg}-1$ (Intraperitoneal injection in mice)

Producing cyanobacteria : Anbaenabergii, Aphanizomenon

ovallsporum, Cylinarospermopsis raciborskil, Umezakia natans, Raphidiopsis curvata

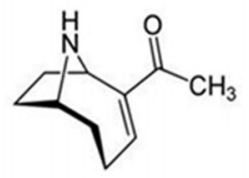

Anatoxin-a : $\mathrm{LD}_{\mathrm{so}}: 200-375 \mu \mathrm{g} \mathrm{kg} \mathrm{g}^{-1}$ (Intraperitoneal injection in mice) Producing cyanobacteria : Anabaena flos-aquae, A. planctonica, A. spiroides, A. circinalis, Aphanizomenon, Cylindrospermum, Microcystis, Oscillatoria spp.

Fig. 1. Classification of cyanotoxins; structures, toxicity and cyanotoxin producers.

일본에서도 1995년 8 9월, 효고 현 니시노미야시의 신 연 못(Shin pond, Nishinomiya, Hyogo, Japan)에서 20여 마리 의 흰뺨검둥오리가 폐사하는 사건이 발생했다. 그 해 1 월 17 일 니시노미야 시를 덮친 한신 - 아와지 대지진에 의해 신 연 못의 상류에 있는 하수처리시설이 파괴되어, 처리되지 않은 하수가 신 연못에 흘러 들어온 것이 녹조현상 발생의 원인이 되었으며, 남조의 한 종류인 Microcystis aeruginosa (Fig. 2) 가 생산하는 독소인 $\mathrm{MC}$ 에 의해 야생조류가 폐사하였으며, 이 사건이 일본에서의 남조에 의한 야생동물 피해의 최초의 보 고이다. ${ }^{4)}$ 이후 2007년 여름, 비와호(Lake Biwa, Shiga, Japan) 의 이소항(Iso fishing port)에서 야생오리 22마리가 폐사하였 으며, 사체의 간에서 $\mathrm{MC}$ 가 검출되었다(Table 1). ${ }^{5)}$ 그 외에도 남조 독소의 가능성이 있는 야생 조류의 사망 기사는 몇 건 있지만, 원인 독소의 분석까지 실행한 사례는 적다.
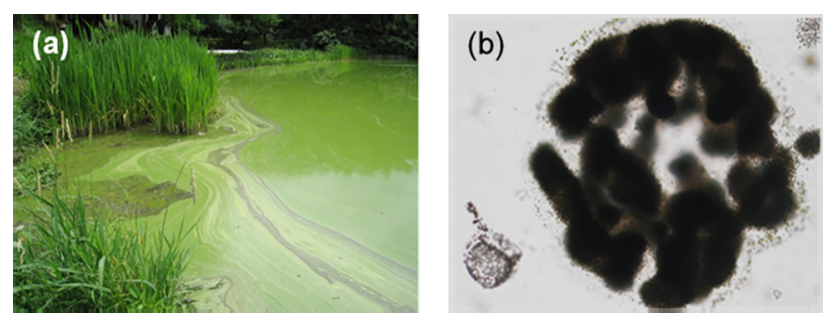

Fig. 2. Cyanobacterial bloom in Chikato-pond, Matsumoto, Japan (a). Photomicrograph of Microcystis aeruginosa (b).
녹조현상을 형성하는 유독남조류는 세계 각지의 부영양 화호수에서 장기간 관찰되고 있다. 남조 독소는 그 화학구 조까지 이미 연구되어 알려져 있지만, 동태에 대해서는 아 직 불분명한 점이 많다. 따라서 본 논문에서는 남조에 의해 생산되는 독소의 생산, 어패류에의 축적, 박테리아에 의한 분해 등 호수생태계에 있어서 남조 독소의 동태와 대책을 소개하고자 한다.

Table 1. Microcystin content in freshwater organisms

\begin{tabular}{|c|c|c|c|c|}
\hline Organism & Organ & \multicolumn{2}{|c|}{ MC concentration } & Sampling site \\
\hline \multicolumn{5}{|l|}{ Gastropod molluscs } \\
\hline Helisoma trivolvis & $\begin{array}{l}\text { Whole } \\
\text { body }\end{array}$ & 37 & $\mu g \cdot g^{-1} \cdot D W^{*}$ & $\begin{array}{l}\text { Lake Driedmeat, } \\
\text { Canada }\end{array}$ \\
\hline Lymnaea stagnalis & $\begin{array}{l}\text { Whole } \\
\text { body }\end{array}$ & 140 & $\mu g \cdot g^{-1} \cdot D W$ & $\begin{array}{l}\text { Lake Steele, } \\
\text { Canada }\end{array}$ \\
\hline Physa gyrina & $\begin{array}{l}\text { Whole } \\
\text { body }\end{array}$ & 129 & $\mu g \cdot g^{-1} \cdot D W$ & $\begin{array}{l}\text { Lake Driedmeat, } \\
\text { Canada }\end{array}$ \\
\hline \multicolumn{5}{|l|}{ Bivalve } \\
\hline Mytilus edulis & $\begin{array}{l}\text { Whole } \\
\text { body }\end{array}$ & 336.9 & $\mu g \cdot g^{-1} \cdot W W^{* *}$ & $\begin{array}{l}\text { Laboratory } \\
\text { experiment }\end{array}$ \\
\hline $\begin{array}{l}\text { Mytilus } \\
\text { galloprovincialis }\end{array}$ & $\begin{array}{l}\text { Whole } \\
\text { body }\end{array}$ & 10.5 & $\mu g \cdot g^{-1} \cdot D W$ & $\begin{array}{l}\text { Laboratory } \\
\text { experiment }\end{array}$ \\
\hline Anodonta woodiana & $\begin{array}{l}\text { Midgut } \\
\text { gland }\end{array}$ & 12.6 & $\mu g \cdot g^{-1} \cdot D W$ & $\begin{array}{l}\text { Lake Suwa, } \\
\text { Japan }\end{array}$ \\
\hline Cristaria plicata & $\begin{array}{l}\text { Midgut } \\
\text { gland }\end{array}$ & 297 & $\mu g \cdot g^{-1} \cdot D W$ & $\begin{array}{l}\text { Lake Suwa, } \\
\text { Japan }\end{array}$ \\
\hline Unio douglasiae & $\begin{array}{l}\text { Midgut } \\
\text { gland }\end{array}$ & 420 & $\mu g \cdot g^{-1} \cdot D W$ & $\begin{array}{l}\text { Lake Suwa, } \\
\text { Japan }\end{array}$ \\
\hline \multicolumn{5}{|l|}{ Arthropod } \\
\hline Zooplankton & $\begin{array}{l}\text { Whole } \\
\text { body }\end{array}$ & 66 & $\mu g \cdot g^{-1} \cdot D W$ & $\begin{array}{l}\text { Lake Driedmeat, } \\
\text { Canada }\end{array}$ \\
\hline Daphnia magna & $\begin{array}{l}\text { Whole } \\
\text { body }\end{array}$ & 24.5 & $\mu g \cdot g^{-1} \cdot D W$ & $\begin{array}{l}\text { Laboratory } \\
\text { experiment }\end{array}$ \\
\hline Bosmina fatalis & $\begin{array}{l}\text { Whole } \\
\text { body }\end{array}$ & 1387 & $\mu g \cdot g^{-1} \cdot D W$ & $\begin{array}{l}\text { Lake Kasumi- } \\
\text { gaura, Japan }\end{array}$ \\
\hline Chaoborus larvae & $\begin{array}{l}\text { Whole } \\
\text { body }\end{array}$ & $\langle 3.9$ & $\mu g \cdot g^{-1} \cdot D W$ & $\begin{array}{l}\text { Laboratory } \\
\text { experiment }\end{array}$ \\
\hline Cancer magister & $\begin{array}{l}\text { Whole } \\
\text { body }\end{array}$ & 84.1 & $\mathrm{ng} \cdot \mathrm{g}^{-1} \cdot \mathrm{DW}$ & $\begin{array}{c}\text { Cypress Island, } \\
\text { Canada }\end{array}$ \\
\hline $\begin{array}{l}\text { Pacifastacus } \\
\text { leniusculus }\end{array}$ & $\begin{array}{l}\text { Midgut } \\
\text { gland }\end{array}$ & trace & & $\begin{array}{l}\text { Laboratory } \\
\text { experiment }\end{array}$ \\
\hline \multicolumn{5}{|l|}{ Fish } \\
\hline Atlantic salmon & Liver & trace & & $\begin{array}{c}\text { Nanaimo, B. C., } \\
\text { Canada }\end{array}$ \\
\hline $\begin{array}{l}\text { Hypophthalichthys } \\
\text { molitrix }\end{array}$ & Liver & 1.16 & $\mu g \cdot g^{-1} \cdot D W$ & $\begin{array}{l}\text { Lake Chaohu, } \\
\text { China }\end{array}$ \\
\hline $\begin{array}{l}\text { Hypophthalichthys } \\
\text { molitrix }\end{array}$ & Liver & 17.8 & $\mu g \cdot g^{-1} \cdot D W$ & $\begin{array}{l}\text { Laboratory } \\
\text { experiment }\end{array}$ \\
\hline Tilapia rendalli & Liver & 2.8 & $\mu g \cdot g^{-1} \cdot D W$ & $\begin{array}{l}\text { Laboratory } \\
\text { experiment }\end{array}$ \\
\hline \multicolumn{5}{|l|}{ Aves } \\
\hline Anas platyrhynchos & Liver & 0.031 & $\mu g \cdot g^{-1} \cdot D W$ & $\begin{array}{l}\text { Lake Taihu, } \\
\text { China }\end{array}$ \\
\hline $\begin{array}{l}\text { Anas platyrhynchos } \\
\text { domestica }\end{array}$ & Liver & 0.56 & $\mu g \cdot g^{-1} \cdot D W$ & $\begin{array}{l}\text { Lake Biwa, } \\
\text { Japan }\end{array}$ \\
\hline
\end{tabular}

${ }^{*}$ DW; Dry weight, ${ }^{*}$ WW; Wet weight 


\section{2. 남조 독소}

남조에 의해 생산되는 독소는 크게 신경독(anatoxin-a, anatoxin-a (s), saxitoxin)과 간독(microcystin, nodularin, cylindrospermopsin)으로 나뉜다. ${ }^{6}$ 그 중 일본의 호수에서 검출된 남조 독소는 간독 $\mathrm{MC}$, 신경독 anatoxin-a, 간장, 신 장, 비장의 괴사를 일으키는 Cylindrospermopsin이 있다(Fig. 1). 현재 MC 생산이 보고된 남조는 Microcystis aeruginosa 를 시작으로 10 종 이상이 알려져 있다. $\mathrm{MC}$ 는 7 개의 아미 노산으로 형성된 환형펩타이드이며, 구성 아미노산의 변화 에 따라 현재까지 90종류(분자량 909 1115) 이상의 MC가 보고되었다.

$\mathrm{MC}$ 는 남조 세포내에 존재하며, 세포막이 손상되면 외부 로 방출된다. 음용수를 통해 생물의 체내에 들어간 $\mathrm{MC}$ 는 간에 특이한 독성을 발현한다. 간세포에서 발현되는 유기 음이온전달단백질(Organic Anion Transporting Polypeptide, oatp)이 선택적으로 $\mathrm{MC}$ 를 세포내에 받아들인다. $\mathrm{MC}$ 는 단 백질포스파타아제(Protein Phosphatase) 타입 1 및 2A와 공 유 결합하여 그 활성을 억제한다. 탈인산화를 담당하는 효 소인 단백질포스파타아제의 활성을 억제함으로써 인산화를 담당하는 효소인 단백질키나제(Protein Kinase)의 활성이 항 진되고, 따라서, 단백질이 과잉 인산화를 초래한다. 급성독 성의 경우, 이러한 과잉 인산화 단백질이 세포골격의 케라 틴(Keratin), 플렉틴(Plectin)의 손상과 세포골격의 파괴 및 아포토시스(Apoptosis)를 유발한다는 보고가 있다. ${ }^{7)}$ 또한, 과잉 인산화 단백질이 암억제유전자 $\mathrm{p} 53$ 에 영향을 미쳐 발 암촉진인자로서 작용하는 것이 밝혀졌다. $\mathrm{MC}$ 를 장기간 복 용함으로써 발현되는 만성독성의 경우, $\mathrm{MC}$ 가 세포내의 미 토콘드리아에 영향을 미쳐 활성산소를 발생시킨다. 활성산 소는 세포막지질 등에 과산화반응을 일으켜 세포막을 변성
시키며, 아포토시스(Apoptosis) 및 간섬유화, 간경변과 함께 간암을 일으킨다고 보고되었다. 한편, $\mathrm{MC}$ 는 간 내에서 시 스테인(Cysteine) 및 글루타치온(Glutathione, $\mathrm{GSH}$ )과 결합 하여 수용성을 높인 후 배출된다(Fig. 3). ${ }^{8)}$

$\mathrm{MC}$ 는 생물에 이러한 심대한 영향을 주기 때문에, 그 독성 을 억제하는 방법에 대한 연구도 이뤄져 왔다. $\mathrm{MC}$ 의 독성 에 관한 연구는 와편모조류가 생산하는 오카다 산(Okadaic acid)의 연구로부터 발전된 것이 많다. 오카다 산은 $\mathrm{MC}$ 처럼 단백질포스파타아제를 억제한다. 이와 유사한 방법으로 항 진된 단백질키나제의 활성을 억제하는 작용이 있는 물질로 서, 식물에 많이 함유되어 있는 플라보노이드(Flavonoids)가 주목받고 있다. 나린진(Naringin)은 자몽 등의 감귤류의 과 피, 과즙 및 종자에 함유된 플라보노이드 성분이며(Fig. 4), 항산화성이 강하고, 항암성 및 콜레스테롤(Cholesterol) 저하 작용이 있어서 의약품 등에 사용이 검토 중이다. 나린진은 랫드의 간세포에 대해 세포골격성분인 케라틴의 손상을 막 았으며, 또한 $\mathrm{MC}$ 에 의한 아포토시스를 억제했다. ${ }^{10)}$

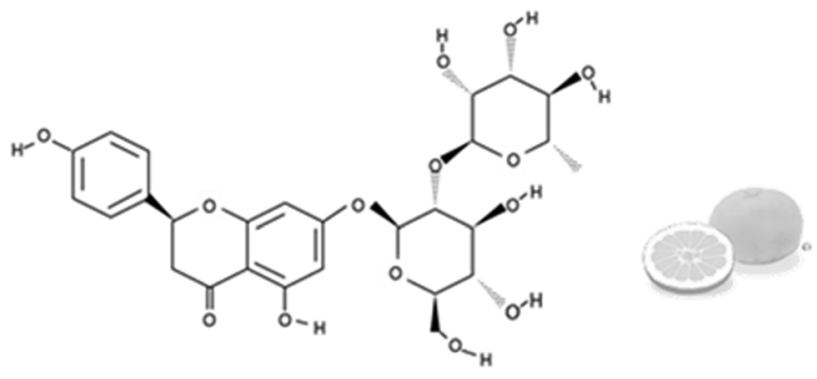

Naringin (MW:580.53, $\mathrm{C}_{27} \mathrm{H}_{32} \mathrm{O}_{14}$ )

Fig. 4. Structure of naringin. Naringin occur naturally in citrus fruits, especially in grapefruit. It is responsible for the fruit's bitter taste.

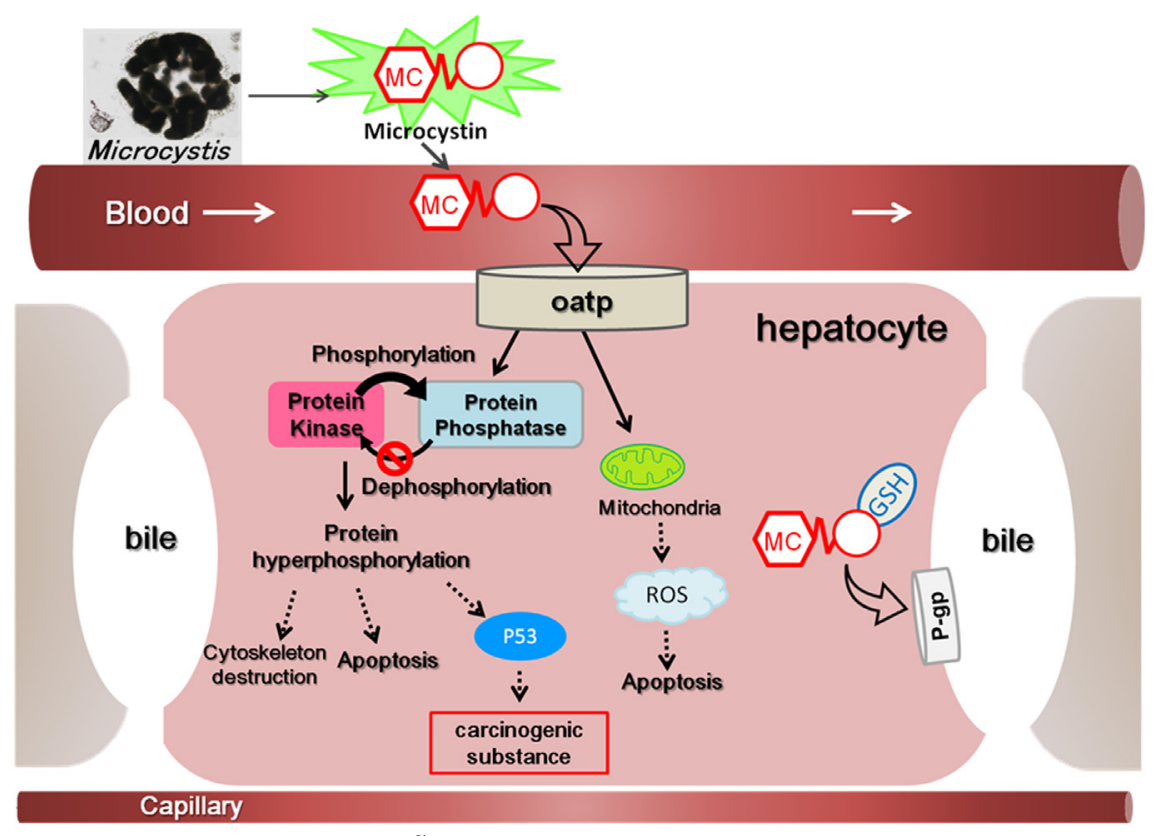

Fig. 3. Toxic effects and metabolism of microcystins. ${ }^{9}$ 
Table 2. Examples of human exposures to cyanobacterial blooms

\begin{tabular}{cccccc}
\hline & Year & Location & Victims & Symptoms & Genera \\
\hline \hline 1 & 1975 & PA, USA & 5,000 people & gastroenteritis & Schizothrix calcicola \\
2 & 1979 & Palm Island, Australia & 148 people & hepatoenteritis & Cylindrospermopsis rachiborskii \\
3 & 1979 & PA, USA & 1 adult and 12 children & Gastrointestinal involvement, hayfever-like symptoms & Anabaena \\
4 & 1989 & Staffordshire, England & $\begin{array}{c}\text { 2 army recruits } \\
\text { (16 year old) }\end{array}$ & $\begin{array}{c}\text { Malaise, sore throat, blistering around the mouth, } \\
\text { vomiting, dry cough and pleuritic pain on the left side }\end{array}$ & Microcystis aeruginosa \\
& & & 116 of 131 patients & Visual disturbance, tintus, nausea, vomiting, muscle & Cyanobacteria \\
5 & 1996 & Caruaru, Brazil & 100 of 116 patients & weakness. Acute liver failure. Deaths & \\
\hline
\end{tabular}

신경독인 Anatoxin-a (Fig. 1)은 캐나다의 호수에서 분리된 Anabaena flos-aquae에 함유되어 있던 독소이며, 동물에 대 해 탈분극에 의한 신경근의 시냅시스 전달을 절단하여 호흡 마비를 일으키기 때문에 사망까지의 시간이 약 4 7분으로 짧다. 마우스에 대한 $\mathrm{LD}_{50}$ 은 200 375 $\mu \mathrm{g} \cdot \mathrm{kg}^{-1}$ 이며, $\mathrm{MC}$ 보 다 독성은 약하다. 일본의 호수에서는 미량의 Anatoxin-a가 검출되었다. ${ }^{11)}$ 또한, 일본의 Anabaena 종 및 Microcystis 종 으로부터 Anatoxin-a가 검출되었다. ${ }^{12)}$ Anatoxin-a는 신경전 달물질로서 방출되는 아세틸콜린(Acetylcholine, Ach)처럼 아세틸콜린수용체(Acetylcholine receptor, AChR)에 결합하며, 아세틸콜린을 가수분해하는 아세틸콜린에스테라아제(Acetylcholinesterase)에 의해 분해되지 않기 때문에 근수축이 계 속 되어 근세포기능이 파괴된다. ${ }^{13)}$

일본산 Umezakia natans가 생산하는 Cylindrospermopsin은 간장, 신장, 비장의 괴사를 일으킨다(Fig. 1). Cylindrospermopsin은 마우스에서 간 및 흥선, 신장, 심장에 대한 영향, 간에서의 단백질 합성의 저해, 배양 간세포에 대한 클루타 치온(Glutathione)의 합성 저해 등이 보고되었다. ${ }^{14)} 1979$ 년 오 스트레일리아의 팜 섬에서 Cylindrospermopsis rachiborskii 블룸이 발생한 물을 황산구리로 처리함에 따라 그 독소 cylindrospermopsin이 세포외로 방출되었으며, 그 물을 식수
로 사용한 결과 주민 150 명(주로 아동)이 간염을 일으켰다 (Table 2). ${ }^{15}$ 최근의 연구에서는 Cylindrospermopsis rachiborskii 이외의 종(Umezaka natans, Aphanizomenon ovalisporum, Anabaena bergii, Raphidiopsis curvata)에서도 cylindrospermopsin이 검출되었다는 보고가 있으며, 호수와 실내배양실 험에서 cylindrospermopsin이 증식기 및 배양조건에 따라 $50 \%$ 이상을 세포외로 방출한다는 보고도 있으므로 정수처 리에 있어서 주의가 필요하다., ${ }^{3,16 ~ 18)}$

\section{3. 남조 독소의 생물에의 축적}

여러 보고로부터 남조에 의해 생성된 $\mathrm{MC}$ 가 호수, 하천 및 해양의 수생생물에 축적된다고 알려져 있다. 야외조사와 실내 $\mathrm{MC}$ 축적 실험으로부터 동물플랑크톤 및 어패류에 대 한 MC의 최대축적농도를 Table 1에 나타냈다.

동물플랑크톤의 $\mathrm{MC}$ 함유량은 실측치 및 계산치로부터 24.5 1387 $\mu \mathrm{g} \cdot \mathrm{g}^{-1}$ (건조중량)이었으며, 어패류는 0.02 337 $\mu \mathrm{g} \cdot \mathrm{g}^{-1}$ (건조중량 또는 습중량)이었다. 특히 해양 쌍각류 조 개(홍합과)의 $\mathrm{MC}$ 축적에 대해서는 몇몇의 연구로부터 실험 적으로 증명되었다. 또한, 해양에서는 게의 유생이 매개가

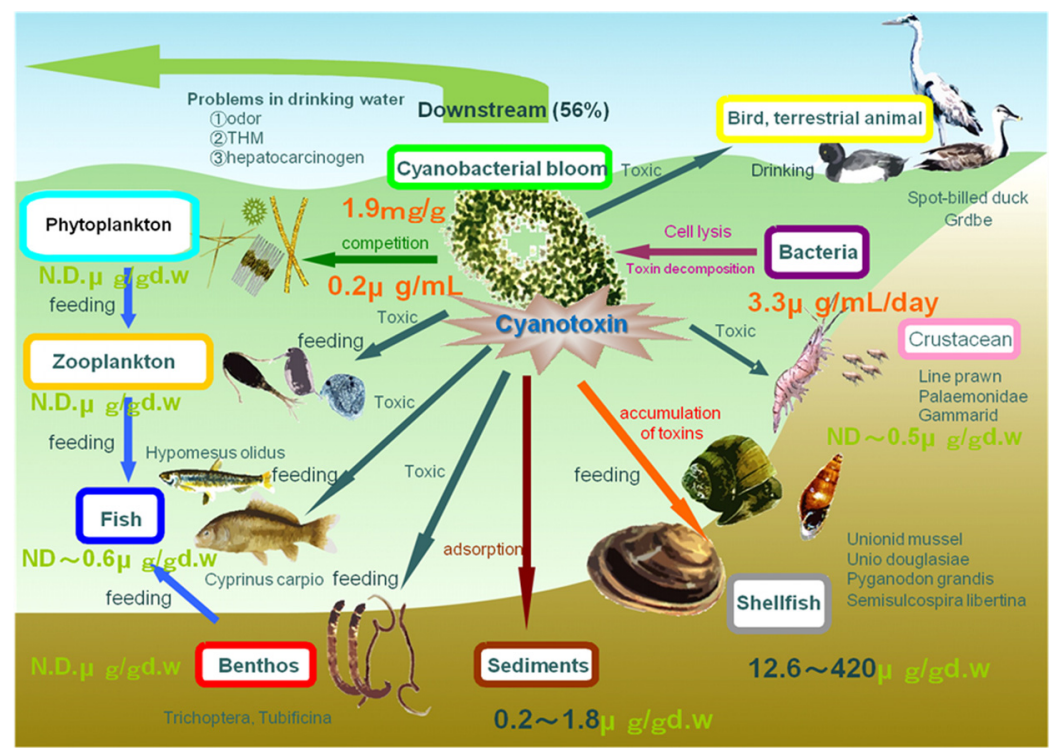

Fig. 5. Dynamics of the microcystin in aquatic ecosystem of Lake Suwa, Japan (Production, feeding, accumulation, degradation and discharge of microcystins). ${ }^{9)}$ 
되어 $\mathrm{MC}$ 가 먹이사슬을 통해 상위 단계(어류)로 옮겨갈 가 능성이 있다. 수와호(Lake suwa, Nagano, Japan)에서는 1992 1998년까지 6 11월까지의 수생동물을 채집, MC 함유량의 정량분석을 통해 먹이사슬을 통한 $\mathrm{MC}$ 의 이동을 조사하였 다(Fig. 5). 그 결과 MC-RR과 -LR이 쌍각류 조개, 고둥 및 갑각류에서 검출되었다. 그 외의 생물의 $\mathrm{MC}$ 함유량은 검출 한계이하였다. 수와호에서 쌍각류 조개의 중장선의 $\mathrm{MC}$ 최 대 축적량은 돌조개가 $420 \mu \mathrm{g} \cdot \mathrm{g}^{-1}$, 말조개가 $297 \mu \mathrm{g} \cdot \mathrm{g}^{-1}$,펄조 개가 $12.6 \mu \mathrm{g} \cdot \mathrm{g}^{-1}$ 으로 종에 따라 큰 차이를 보였다. 특히, 독소 함유량이 높은 돌조개의 부분별 $\mathrm{MC}$ 함유량을 보면, 중장선에서 $53 \%$, 아가미와 근육에서 $34 \%$, 생식선에서 $6 \%$, 소화관에서 $7 \%$ 가 검출되었으며, $\mathrm{MC}$ 의 상당량이 조개의 간 에 해당하는 중장선에 축적되는 것을 알 수 있다. 포유동물 에 대한 급성, 만성 독성 실험에서도 $\mathrm{MC}$ 는 강한 간독성을 갖는 것이 알려졌으며, $\mathrm{MC}$ 투여 후 대부분이 간에 모여 있 는 것으로부터, 조개의 간에 해당하는 중장선에 반 이상의 $\mathrm{MC}$ 가 존재하는 것에 대해 설명할 수 있다. 또한, 수와호에 서 채집한 돌조개를 $\mathrm{MC}$ 가 없는 조건에서 3 개월간 사육한 결과, $\mathrm{MC}$ 함유량이 초기농도의 $10 \%$ 수준으로 감소하였다.

다른 생물에의 $\mathrm{MC}$ 의 이동에 대해 세계 각지의 여러 수역 에서 연구되고 있지만, 현재까지 생물농축에 대한 보고는 없 다. 남조 독소는 남조류를 직접 섭취하는 포식자(1차 소비자 인 수생동물)에는 고농도의 $\mathrm{MC}$ 의 축적이 있지만, 2 차 이후 의 소비자에서는 상위 단계로 갈수록 농도가 감소하는 경향 이 보고되었다. ${ }^{19)}$ 이러한 점에 대해서는 이후에도 많은 생물 에 대한 조사가 이루어져 그 실태를 분명히 할 필요가 있다.

한편, 수와호(Lake Suwa, Japan)에서 발생했던 남조의 $56 \%$ 는 텐류강(Tenryu-gawa River, Japan)으로 떠내려가는 것이 밝혀졌다. 떠내려가는 남조(Fig. 6)는 수생곤충의 먹이가 된 다고 보고되었으며, 남조 독소가 수염치레각날도래(히게나 가카와토비케라)의 유충에서 성충까지 검출되었다(Fig. 7). 따라서 텐류강에 흘러간 $\mathrm{MC}$ 는 어류, 육식곤충 또는 조류에 이동할 가능성을 시사한다. ${ }^{20)}$

호수나 유속이 느린 하천에서 발생하는 남조는 결국 바다 에 다다른다는 보고가 수 년 전부터 늘고 있다. 이렇게 흘

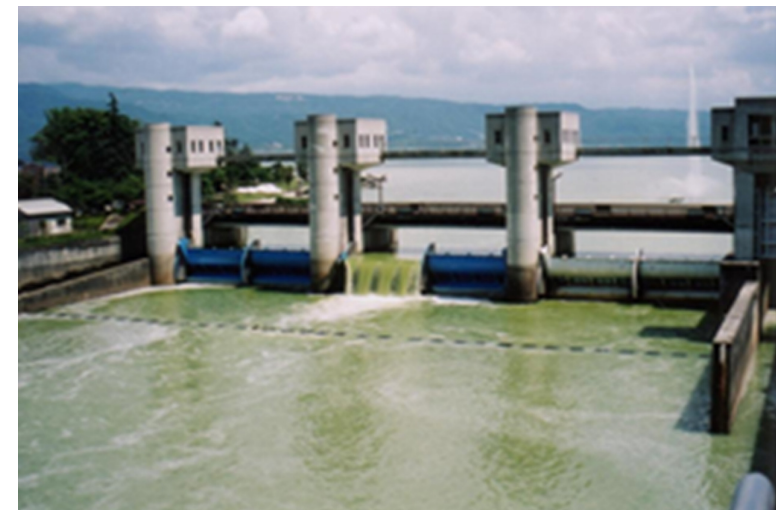

Fig. 6. Discharge of cyanobacterial blooms from Lake Suwa to Tenryu River, Japan (Kamaguchi water gate and Tenryu River)

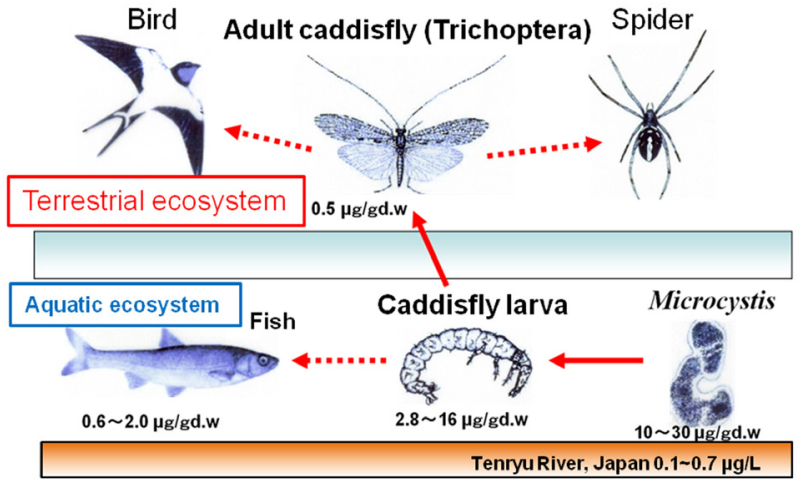

Fig. 7. Dynamics of the microcystin in aquatic ecosystem of Tenryu River, Japan. ${ }^{21)}$

러가는 과정에서도 독소는 생산되며, 다른 생물로 이동할 수 있기 때문에 각 수역에서의 생물에의 독성 영향과 축적 이 염려되며, 식품으로 이용할 경우 안정성평가가 필요하다. 미국 캘리포니아 주 클라마스강(Klamath River, California, USA) 및 샌프란시스코(San Francisco, California, USA) 주 변 하천으로부터 남조 독소가 떠내려와, 연안에 서식하는 꽃게 등의 어패류의 중장선에서 남조 독소가 검출되었으며, 이로 말미암아 식품위생상의 문제가 대두되고 있다. ${ }^{22)}$ 일본 아리아케해(Ariake Sea)의 이사하야만(Isahaya Bay, Japan) 의 조정지가 완성되고 수년 후부터 매년 여름 녹조현상이 나타나고, 바다에 흘러들어 굴 및 꽃게 등에서 남조 독소가 축적되었다는 보고가 있다. ${ }^{23)}$

\section{4. 남조 독소 $\mathrm{MC}$ 의 분해와 제거 방법}

남조 독소 중 Anatoxin과 Cylindrospermopsin (Fig. 1)은 세포 성장 단계 중 성장 초기에는 세포내에 존재하다가 성 장 후기에는 세포외로 배출된다는 보고가 있다. 하지만, $\mathrm{MC}$ 는 세포내에서 존재하는 것이 알려져 있으며, $\mathrm{MC}$ 의 제거는 세포 그대로를 제거하는 것이 최선의 방법이다. 물론 세포 에서 용출된 $\mathrm{MC}$ 를 제거할 수 있지만 막대한 비용이 든다는 단점이 있다. 자연계에서는 포식자에 의한 남조세포의 섭식 또는 남조세포로부터 용출된 microcystin의 미생물에 의한 분해에 의해 microcystin의 제거가 가능하지만, 정수처리 과정에서는 microcystin을 분해하는 미생물이 존재하지 않 으므로, 세포제거를 위해 황산구리를 사용할 경우 대량의 microcystin이 용출되므로 주의가 필요하다.

지금까지의 보고에 의하면 세포 밖으로 용출된 $\mathrm{MC}$ 를 제 거하는 기술은 물리, 화학 및 생물학적 방법이 있다. 물리 적 방법 중에는 용존유해물질의 제거에 일반적으로 사용되 는 활성탄여과가 있다. 활성탄여과법은 활성탄의 종류에 의 해 흡착량이 변하며, 활성탄 $1 \mathrm{~g}$ 에 최대 $0.7 \mathrm{~g}$ 의 $\mathrm{MC}$ 를 흡착 시킬 수 있다고 알려졌다. 분말활성탄의 경우 $\mathrm{MC}$ 제거율은 $20 \%$ 에서 최대 $85 \%$ 이지만, 입상활성탄의 경우 $90 \%$ 이상의 제거가 가능한 것으로부터 입상활성탄을 이용한 여과가 제 거능력이 높다는 것을 알 수 있다. ${ }^{24)}$ 활성탄여과법은 일본 
정수처리장에서 조류가 내는 악취를 제거하기 위해 통상적 으로 사용되며, 그 외 일반 가정용 정수기에서도 사용된다. 또 다른 물리적 방법으로 역삼투법이 있다. 이 방법은 물분 자 정도만이 통과할 수 있는 반투막을 이용하여 정수처리 하는 방법으로 통상적으로 분자량 100 이상의 유기물을 제 거할 수 있다. 역삼투법에 의한 $\mathrm{MC}$ 의 제거율은 $95 \%$ 이상 으로, 도쿄의 카나마치 정수장(Kanamachi water purification plant, Tokyo, Japan)에서는 이러한 방법으로 정수처리 하고 있다. 화학적 방법으로는 염소, 오존, 과망간산칼륨 및 광분 해에 의한 처리 등이 보고되고 있다. 염소는 $\mathrm{pH} 5$ 에서 차아 염소산염을 형성하기 시작하여 $\mathrm{pH} 10$ 에서 완전히 이온화 되므로, $\mathrm{pH}$ 5에서는 30분간 처리로 $93 \%$ 의 $\mathrm{MC}$ 를 무독화 시킬 수 있었다. 하지만, $\mathrm{pH} 7$ 의 경우 22 시간 처리로 $88 \%$ 무독화 시켰으며, 분해율은 $\mathrm{pH}$ 7의 경우 $79 \%$ 이지만, $\mathrm{pH}$ 10 의 경우 $0.5 \%$ 까지 감소하였다. ${ }^{25)}$ 이는 산화력이 강한 치 아염소산의 감소에 의한 것이라 사료된다. 염소처리에 의 한 $\mathrm{MC}$ 의 제거는 처리수의 $\mathrm{pH}$ 가 중성에서 산성이어야 된 다. 하지만, 남조가 번무한 수원지는 $\mathrm{pH}$ 가 염기성일 경우 가 많으므로 주의가 필요하다. 오존처리는 원수를 오존가스 로 살균하는 방법으로 염소를 대체하는 방법 중 하나이다. 특히 발암물질인 트리할로메탄(Trihalomethane, THM)의 형 성이 우려되는 수원지에 좋은 방법이다. 하지만, 염소보다 비용이 많이 들며 발암물질인 포름알데히드(Formaldehyde) 가 생성되는 문제가 있다. 오존처리에 의한 $\mathrm{MC}$ 의 분해율은 $99 \%$ 로 높은 분해능력을 보이지만, 그 분해물이 생물에 미 치는 영향에 대해 아직 알려져 있지 않다. ${ }^{26)}$ 과망간산칼륨 처리에 의한 $\mathrm{MC}$ 의 제거율은 $95 \%$ 정도로 염소처리와 비슷 한 수준이다. ${ }^{26)}$ 태양광에 의한 $\mathrm{MC}$ 분해는 촉매 없이는 효 과가 낮아서 실험개시 26 일 후 $\mathrm{MC}$ 의 잔존율이 $86 \%$ 였다. 하지만, 피코시아닌(Phycocyanin)이 존재할 경우 실험개시 29 일 후 $\mathrm{MC}$ 의 분해율이 $95 \%$ 였다. ${ }^{27)}$ 전기분해는 수용액의 전기분해시 양극에서 발생하는 활성화 산소 및 염소를 이 용하여 남조류 및 독소를 제거하는 방법이며, 실험실 실험 의 결과 남조류 Microcystis 및 $\mathrm{MC}$ 의 분해율은 $95 \%$ 이상이 었다. 또한, 모네타이트 및 브루사이트가 음극 표면에 석출 됨으로써 지속적인 인의 제거가 가능하며, 양극으로부터 발 생하는 산소를 이용하여 호수 퇴적층의 혐기화를 개선시킬 수 있다. ${ }^{28)}$ 일반적으로 사용되는 전극인 백금의 경우 가격 이 비싼 단점이 있지만, 최근 세라믹(금속산화물) 전극의 개발로 보다 싸고 살조능력은 향상되었다. 하지만, 아직 실 험실 규모의 보고밖에 없으며, 대규모의 호수에 적용시키기 위한 연구가 필요하다. 그 외에도 과산화수소, 자외선 조사 및 광촉매를 이용하는 처리방법 등이 연구되고 있다. ${ }^{29)}$

알루미늄 응집제(Aluminium sulfate 등, 이하 alum)는 배 수 및 정수처리, 번무한 조류의 억제에 가장 일반적으로 사 용되어 왔다. 정수처리와 호수의 녹조현상 제어를 위한 alum 처리에 대한 지금까지의 대부분의 연구는, alum 처리가 세 포에 손상을 주지 않으며, 남조 독소 $\mathrm{MC}$ 가 세포외로 용출 되지 않는다고 주장했다. 하지만, 최근 연구에 의하면 alum
처리에 의한 세포손상은 처리시간이 중요하다는 것이 알려 졌다. 일반적인 정수처리는 24시간을 넘기지 않지만, 호수에 서 녹조현상 제어를 위한 alum 처리는 수개월 걸릴 수도 있 으므로, 남조 독소 $\mathrm{MC}$ 가 세포외로 용출되는 것은 충분히 상정할 수 있다. 따라서, 호수에 대한 녹조현상 제어를 위 한 alum 처리는 호수의 퇴적층에 오랜 기간 alum이 잔류하 는지, alum 처리 후 남조 독소가 용출하는지에 대해 충분히 고려할 필요가 있다. ${ }^{30)}$

생물을 이용한 $\mathrm{MC}$ 의 분해 및 제거는 박테리아, 원생동물 및 윤형동물 등을 이용하는 방법이 연구되고 있다. $\mathrm{MC}$ 는 물리, 화학적 방법으로 분해하기 어려운 매우 안정적인 물 질이다. 하지만, 1992년에서 1994년까지 수와호(Lake Suwa, Nagano, Japan)에서의 $\mathrm{MC}$ 의 거동으로부터, 대부분의 $\mathrm{MC}$ 는 조류 세포 내에 존재하며, 수중에 용존하는 $\mathrm{MC}$ 의 양은 조 류 세포내의 함유량과 비교할 때 미량(수 $\mu \mathrm{g} \cdot \mathrm{L}^{-1}$ 이하)인 것 이 확인되었다. 또한 용존 상태의 $\mathrm{MC}$ 의 농도는 조류 번무 현상의 붕괴기에도 미량으로 유지되었다. 이러한 결과로부 터, 호수중의 무엇인가에 의해 $\mathrm{MC}$ 가 분해될 가능성이 시 사된다. 이에 박테리아에 의한 $\mathrm{MC}$ 의 분해에 주목하였으며, 수와호에서 분리, 동정한 박테리아 16 주에 대하여 $\mathrm{MC}$ 분

Table 3. Bacterial degradation rate of microcystin ${ }^{45)}$

\begin{tabular}{|c|c|c|c|c|}
\hline Microorganism & Strain & $\begin{array}{c}\text { MC- } \\
\text { degrading } \\
\text { enzyme }\end{array}$ & $\begin{array}{c}\text { Degrada- } \\
\text { tion rate } \\
\left(\mathrm{mg} \mathrm{L}^{-1} \text { day }^{-1}\right)\end{array}$ & $\begin{array}{c}\text { Refe- } \\
\text { rences }\end{array}$ \\
\hline Spingomonas sp. & $\begin{array}{l}\text { ACM-3962 } \\
\text { (AF401173) }\end{array}$ & mirA & 12.1 & 31) \\
\hline $\begin{array}{l}\text { Spingosinicella } \\
\text { microcystinivorans }\end{array}$ & $\begin{array}{c}\text { Y2(AF401174) } \\
\text { MDB2 } \\
\text { (AB219940) } \\
\text { MDB3 } \\
\text { (AB219941) }\end{array}$ & mirA & $5.4-13$ & $\begin{array}{l}32) \\
33)\end{array}$ \\
\hline Spingopyxis sp. & $\begin{array}{c}\text { LH21 } \\
\text { (DQ112242) }\end{array}$ & mlrA & 0.002 & 34) \\
\hline do. & $\begin{array}{c}\text { T125 } \\
\text { (JQ398614) }\end{array}$ & mlrA & 0.06 & 35) \\
\hline do. & $\begin{array}{l}\text { USTB-05 } \\
\text { (EF607053) }\end{array}$ & mlrA & 101 & $\begin{array}{l}36) \\
37)\end{array}$ \\
\hline Bacillus sp. & $\begin{array}{l}\text { AMR1-03 } \\
\text { (GU294753) }\end{array}$ & mlrA & 2 & 38) \\
\hline $\begin{array}{l}\text { Stenotrophomonas } \\
\text { sp. }\end{array}$ & $\begin{array}{c}\text { EMS } \\
\text { (FJ712028) }\end{array}$ & mirA & 1.2 & 39) \\
\hline $\begin{array}{l}\text { Novospingobium } \\
\text { sp. }\end{array}$ & $\begin{array}{c}\text { THN1 } \\
(\mathrm{HQ664117)}\end{array}$ & mlrA & 2.55 & 40) \\
\hline $\begin{array}{l}\text { Psedomonasa } \\
\text { aeruginosa }\end{array}$ & - & - & 2.4 & 41) \\
\hline $\begin{array}{l}\text { Ralstonia } \\
\text { solanacearum }\end{array}$ & - & - & $29.5-50.5$ & 42) \\
\hline $\begin{array}{l}\text { Paucilbacter } \\
\text { toxinivorans }\end{array}$ & - & - & $0.096-0.384$ & 43) \\
\hline Burkholderiasp. & DQ459360 & - & 0.05 & 44) \\
\hline Methlylobacillus sp. & J10(FJ418599) & - & $4.9-6.3$ & 45) \\
\hline $\begin{array}{l}\text { Trichaptum } \\
\text { abietinum }\end{array}$ & 1302BFG & - & 0.08 & 46) \\
\hline
\end{tabular}


해능력의 유무를 확인하였다. 그 결과, 14 주의 $\mathrm{MC}$ 분해율 은 20 일 동안 최대 약 $20 \%$ 였지만, 새로운 속, 새로운 종으 로 확인된 $\mathrm{Y} 2$ (Spingosinicella microcystinivorans)는 20 $\mathrm{mg} \cdot \mathrm{L}^{-1}$ 의 $\mathrm{MC}$ 를 6 일 동안 완전 분해했다. 이 실험으로부터 호수에서 다음과 같은 $\mathrm{MC}$ 분해기구가 고려된다. 호수에서 발생한 Microcystis에 의해 생산된 MC는 세포의 자기분해 또는 박테리아에 의한 조류세포의 분해에 의해 호수중으로 용출되고, $\mathrm{Y} 2$ 주를 포함한 $\mathrm{MC}$ 분해 박테리아 군집에 의해 빠르게 분해된다고 사료된다. $\mathrm{MC}$ 분해 박테리아는 12속 이상 보고되었지만, 종까지 동정된 것은 5종뿐이다(Table 3). 2001년 오스트리아에서 ACM-3962 주의 MC 분해효소를 코 딩하여 4 개의 유전자 $(\mathrm{mlrA}, \mathrm{mlrB}, \mathrm{mlrC}, \mathrm{mlrD})$ 를 알아냈다. $\mathrm{MC}$ 분해효소 $\mathrm{mlrA}$ 는 고리구조 $\mathrm{MC}$ 를 직쇄상으로 가수분 해하는 효소이며, $\mathrm{mlrB}$ 와 $\mathrm{mrlC}$ 는 직쇄상의 $\mathrm{MC}$ 를 더욱 세 분화(테트라펩타이드와 저분자 아미노산) 시키는 효소이다. $\mathrm{mlrD}$ 는 박테리아 외에 존재하는 $\mathrm{MC}$ 를 세포내로 끌어들이 는 수송단백질(Transporter protein)이다. 6속의 박테리아에 서 $\mathrm{MC}$ 분해효소 $\mathrm{mlrA}$ 가 확인되었으며, $\mathrm{MC}$ 분해속도는 실험조건에 따라 차이가 있었다. 최적의 조건에서 $\mathrm{MC}$ 분해 효소에 의한 $\mathrm{MC}$ 분해속도는 수 십에서 수 백 $\mathrm{mg} \cdot \mathrm{L}^{-1} \cdot \mathrm{day}^{-1}$ 이었다. ${ }^{47)}$ 따라서 살조제 등으로 인한 $\mathrm{MC}$ 분해 박테리아의 성장을 저해하는 요인이 없는 환경에서는 호수의 용존 상 태의 $\mathrm{MC}$ 는 수 일내로 분해 될 것이라 예상된다.

지금까지의 수와호에서의 남조 독소의 거동에 관한 연구 결과를 Fig. 5에 요약했다. 남조 독소의 계절변화 및 경년변 화 결과로부터 $\mathrm{MC}$ 농도의 상한 및 하한 범위를 알 수 있 다. ${ }^{47)}$ 또한, 호수에서의 $\mathrm{MC}$ 는 대부분 Microcystis 세포내에 존재하며, 용존 상태의 $\mathrm{MC}$ 는 미량인 것은, 박테리아 군집 에 의한 분해기구의 존재에 의해 설명된다. 수와호 퇴적층 에 함유된 $\mathrm{MC}$ 의 존재유무에 대해서는 아직까지 확인되지 않았지만, 실내실험으로부터 퇴적층에 $\mathrm{MC}$ 가 흡착할 수 있 다는 것이 확인되었다. 퇴적층에 $\mathrm{MC}$ 를 첨가하는 실험으로 부터 퇴적층의 $\mathrm{MC}$ 흡착율을 측정하였다. 그 결과 $\mathrm{MC}$ 의 최 대 흡착량은 $\mathrm{MC}-\mathrm{RR}$ 이 $1,860 \mu \mathrm{g} \cdot \mathrm{g}^{-1}, \mathrm{MC}-\mathrm{LR}$ 이 $640 \mu \mathrm{g} \cdot \mathrm{g}^{-1}$ 으로 $\mathrm{MC}-\mathrm{RR}$ 이 MC-LR보다 약 3 배 많았다. 흡착된 $\mathrm{MC}$ 를 재현성 좋게 분리하기는 힘들며, 정성, 정량 분석은 어렵기 때문에 새로운 분석방법이 필요하다. 쌍각류 조개가 남조 독소를 축적, 농축한다는 사실은 조개 이외의 수생생물의 축 적과 생물농축의 가능성이 있으며, 이후의 연구과제로서 주 목할 필요가 있다. 또한, 우리는 남조 독소를 분해하는 특 이한 박테리아를 수와호에서 분리했다. 이러한 균을 이용하 여 $\mathrm{MC}$ 분해 박테리아의 동태를 알아내고, $\mathrm{MC}$ 분해 기구를 상세히 해명한다면, 수원지에서의 남조 독소의 처리에 대한 응용이 기대된다. ${ }^{48)}$

Table 4에 녹조현상의 현상의 발생조건을 나타내었다. 녹 조현상의 방지는 그 발생의 원인인 호수 외로부터 유입되 는 영양염류인 질소와 인의 감소가 기본이다. 수와호를 비 롯한 여러 수역에서는 부하 발생원에서의 대책을 가장 중요 하며, 적절한 수단이라고 하지만, 투자에 비해 그 효과는 높
Table 4. Causes of formation and inhibition of cyanobacterial blooms

\begin{tabular}{|c|c|c|}
\hline Factors & Conditions of formation & Conditions of inhibition \\
\hline Water temperature & $>15 \sim 20^{\circ} \mathrm{C}$ & $\left\langle 15^{\circ} \mathrm{C}\right.$ \\
\hline $\mathrm{pH}$ & $>7 \sim 8$ & $\langle 7$ \\
\hline Solar radiation & High & Low \\
\hline P concentration & High & Low \\
\hline $\mathrm{N}$ concentration & $\begin{array}{l}\text { High (except N2- } \\
\text { fixing cyanobacteria) }\end{array}$ & $\begin{array}{l}\text { Low (except N2- } \\
\text { fixing cyanobacteria) }\end{array}$ \\
\hline N/P ratio & Low & High \\
\hline Water movements & Stratified & Well-mixed by wind \\
\hline Retention time & Long (> several months) & Short (〈several weeks) \\
\hline Discharge & $\begin{array}{c}\text { Metalimnetic/ } \\
\text { hypolimnetic discharge }\end{array}$ & Epilimnetic discharge \\
\hline $\begin{array}{l}\text { Condition of } \\
\text { sediments }\end{array}$ & $\begin{array}{c}\text { Anaerobic } \\
\text { (extraction of } \mathrm{Fe} \text { and } \mathrm{P})\end{array}$ & Aerobic \\
\hline Trace element & High bioavailable Fe & Low bioavailable Fe \\
\hline Predators & $\begin{array}{l}\text { Low (herbivorous fish } \\
\text { and shellfish) }\end{array}$ & $\begin{array}{l}\text { High (zooplankton, } \\
\text { rotifers and protozoa) }\end{array}$ \\
\hline $\begin{array}{l}\text { Cyanobacteria } \\
\text { degrading } \\
\text { microorganisms }\end{array}$ & Low & $\begin{array}{l}\text { High (bacteria, } \\
\text { fungi and viruses) }\end{array}$ \\
\hline $\begin{array}{l}\text { Aquatic } \\
\text { macrophytes }\end{array}$ & Low & $\begin{array}{l}\text { High (floating-leaved } \\
\text { macrophytes and } \\
\text { submerged } \\
\text { macrophytes) }\end{array}$ \\
\hline
\end{tabular}

지 않다. 그 이유는 호수생태계에서 이미 유입되어온 영양 염류를 축적하고 있으며, 재이용하는 기구를 가지고 있기 때문이다. 특히, 퇴적층에의 영양 성분의 축적은 인위적으로 부영양화 된 호수의 회복을 늦추는 원인의 하나이다. 하지 만 그렇다고 해서 함부로 호수의 퇴적층의 전면적 준설, 제 거하는 등의 대책은 적절하다 할 수 없다. 일본 비와호처럼 남조 세포의 농도가 낮지만 남조 현상의 성질 중 하나인 표 층에의 집적으로 인해 위험성이 높아질 수 있다(Fig. 8). ${ }^{49)}$

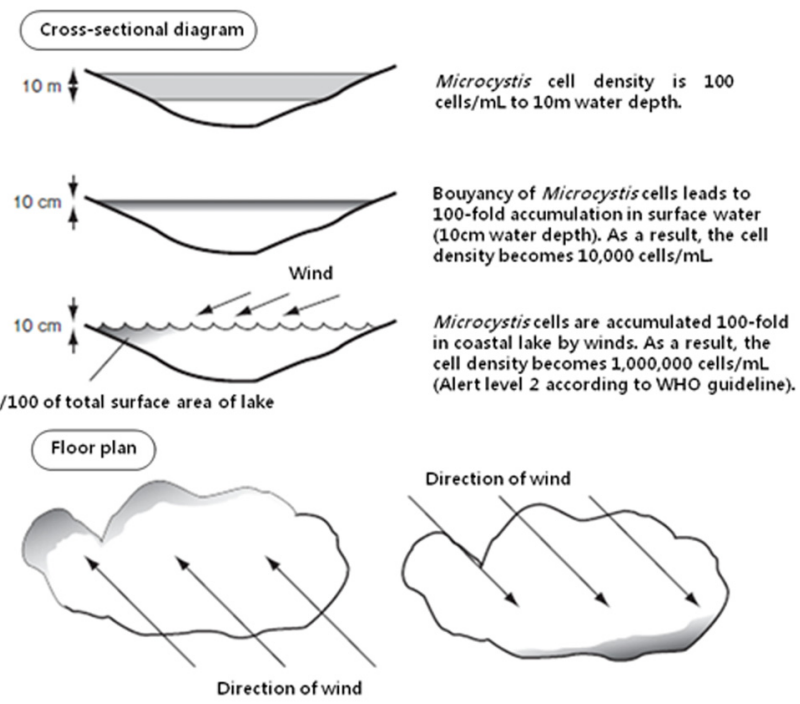

Fig. 8. Schematic illustration for the integration of Cyanobacterial blooms by wind. ${ }^{47)}$ 
Table. 5. Prevention and control of cyanobacterial blooms (Kwater)

\begin{tabular}{|c|c|c|c|}
\hline Factors & $\begin{array}{l}\text { Physical } \\
\text { technology }\end{array}$ & $\begin{array}{l}\text { Biological } \\
\text { technology }\end{array}$ & $\begin{array}{l}\text { Chemical } \\
\text { technology }\end{array}$ \\
\hline $\begin{array}{c}\text { Existing } \\
\text { technologies }\end{array}$ & 14 & 11 & 7 \\
\hline $\begin{array}{c}\text { Prevention } \\
\text { and control of } \\
\text { cyanobacterial } \\
\text { blooms }\end{array}$ & $\begin{array}{l}\text { inlet water con- } \\
\text { version, circulation, } \\
\text { deep aeration, } \\
\text { deep water } \\
\text { discharges }\end{array}$ & $\begin{array}{l}\text { red clay, } \\
\text { coagulant, } \\
\text { algicide, } \\
\text { phosphorus } \\
\text { inactivation }\end{array}$ & $\begin{array}{l}\text { protozoan, } \\
\text { microorganism } \\
\text { algicide, } \\
\text { fish }\end{array}$ \\
\hline Risks & $\begin{array}{c}\text { high-cost/ } \\
\text { uneconomical }\end{array}$ & $\begin{array}{l}\text { secondary } \\
\text { pollution }\end{array}$ & $\begin{array}{c}\text { lower } \\
\text { practicality }\end{array}$ \\
\hline
\end{tabular}

부영양 호수 또는 하천에서 조류대발생으로 증가된 수중 내 유기물질을 제어하는 것은 수자원 문제해결의 가장 핵심 적인 부분이며, 적용될 기술 역시 경제성이 높고 생태계 혼 란이 가장 적은 친환경적인 기술의 개발이 필요하다. 기존의 녹조제거기술(황토, 황산구리, 클로린 등의 화학물질을 수 계에 직접 살포하는 방법이나 심층포기, 강제순환, $\mathrm{UV}$, 초 음파 등)은 그 효과는 인정되지만 비용이 많이 소요되고 일 시적이며 타생물에 대한 독성을 보이거나 화학물질에 의한 2 차적 환경오염 등을 유발하며, 적용 수계의 규모와 환경적 특징에 따라 적용이 어려운 경우와 효과가 미미한 경우도 다 수 발생하기도 한다. 녹조 저감 기술은 물리적, 생물학적, 복 합 저감 기술 등 4 가지로 분류할 수 있으며, 물리적 기술은 사전 및 사후 처리기술에 공통적으로 이용될 수 있으나, 화 학 및 생물학적 기술은 주로 사후처리에 해당한다고 할 수 있다. Table 5에 녹조 저감에 사용되는 기술을 나타내었다. 녹조현상의 발생을 방지하기 위해 폐수처리 및 물의 정화 등 의 물리화학적 예방적 기술이 다방면으로 개발되어 있다.
최근 일본의 많은 호수에서는 연안부의 인공화가 진행됨 에 따라 본래의 호수에서 볼 수 있던 수생식물을 볼 수 없 게 되었다. 호수가 본래의 상태일 때 부영양화 된다면, 호 수의 연안부에 수생식물의 침입이 일어나고, 식물플랑크톤 에 의한 조류 번무 현상은 보이지 않는 것이 보통이다. 조 류 번무 현상이 보이는 것은 수생식물이 적고, 개수면이 넓 은 연못과 같은 상태이기 때문이다. 수생식물의 존재는 식 물플랑크톤의 발생을 제어한다는 예가 많다. 그 내용으로는 호수 외에서 유입된 영양염류를 연안부에서 흡수하고 호수 에 직접 유입되는 것을 막아 육지와 연안의 완충지의 역할, 수생식물에서 방출되는 물질에 의한 알레로파시(Allelopathy) 등이 있다.

이러한 관점으로부터 녹조현상 발생방지를 위해서는 일 단 호수 연안을 정상적인 상태로 복원할 필요가 있다. 최근 에는 호수 연안의 중요성에 대해서도 양적으로 평가할 수 있게 되었으며, 그에 대한 수복공사도 사업화 되었다. 상당 부분 인공적으로 개변되어 녹조현상의 발생을 조장했던 수 와호에서도 연안의 수복을 실행에 옮기고 있다. 녹조현상 기구와는 직접적으로 관계없는 것처럼 보이는 연안의 수복 이 실제로는 크게 관계한다는 것을 이해할 필요가 있다. 마 찬가지로 집수역에서의 영양염류 유입에는 산지의 인위적 인 개발이 크게 관계하고 있으며, 녹조현상의 방지에는 수 원지의 산림, 하천 강변의 숲의 보전 역시 중요한 대책인 것 을 인식할 필요가 있다.

\section{5. 결 론}

남조 독소에 의한 동물의 사망은 1870 년대 오스트레일리

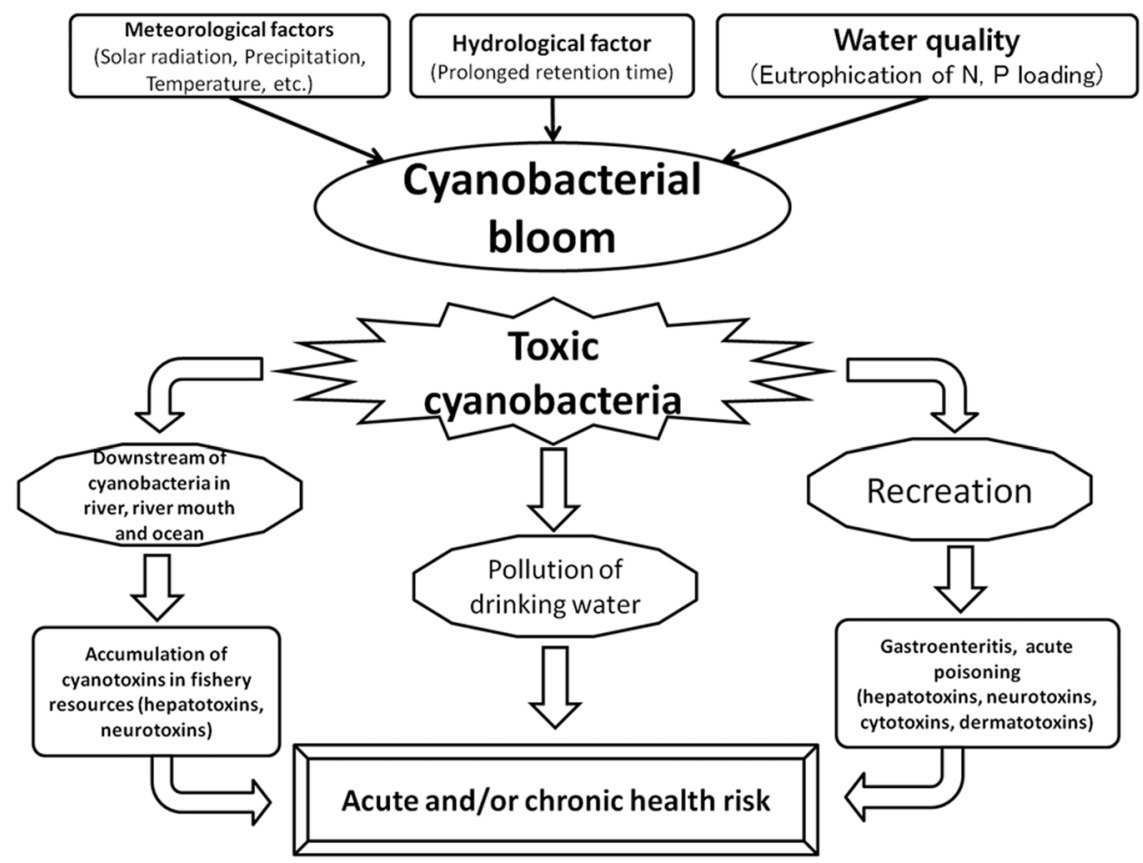

Fig. 9. Occurrence of harmful cyanobacterial blooms and health risks thereby. 
아에서의 Nodularia spumigena에 의한 보고를 시작으로, 1995년에서 1998년까지 캐나다에서 일어난 야생 조류의 폐 사(26만 마리 이상)까지 다수의 사례가 보고되고 있다. 그 럼에도 불구하고 이렇다 할 대책을 세운 나라는 아직 없다. 그리고, 1996년 2월 브라질의 카루아루(Caruaru)에서는 수 원지의 남조 독소의 혼입에 의해 50 명 이상의 투석환자가 사망한 사건도 발생했다. 일본에서도 상수도 수원지인 호수 및 댐에서 유독 남조류가 발생했다는 예도 있어 상수도를 통한 인체에의 영향이 우려된다(Fig. 9).

자연 호수 및 댐을 상수도의 수원지로 하는 나라에서는 수원지의 부영양화의 진행에 의한 유독 남조류의 발생에 골치가 아픈 것이 현재의 상황이다. 음용수 중의 남조 독소 $\mathrm{MC}$ 에 대한 가이드라인을 최초로 설정한 나라는 오스트레 일리아이다. 오스트레일리아의 조류 독의 가이드라인에서는 음용수 중 $\mathrm{MC}$ 농도는 단기노출(14일 이상 노출)일 때 1.0 $\mu \mathrm{g} \mathrm{L}^{-1}$, 장기노출(일생 노출)일 때 $0.1 \mu \mathrm{g} \mathrm{L}^{-1}$ (Microcystis 세포수로 500 cells $\mathrm{mL}^{-1}$ )로 두 개의 기준을 설정하였다. 그 후 세계보건기구 $(\mathrm{WHO})$ 에서는 성인 $(60 \mathrm{~kg})$ 한 명이 매일 평 균 2 리터의 물을 마시는 것과 MC-LR의 1 일 섭취 허용량 $\left(0.04 \mu \mathrm{g} \mathrm{kg}\right.$ body weight $\left.{ }^{-1} \mathrm{day}^{-1}\right)$ 의 연구결과를 고려하여 음 용수 중 $\mathrm{MC}-\mathrm{LR}$ 의 농도 $1.0 \mu \mathrm{g} \mathrm{L}^{-1}$ 을 가이드라인으로 채택 했다. ${ }^{50)}$ 미국에서는 오리곤 주(State of Oregon)만이 식품중 의 가이드라인 값이 제정되어 있지만, 2013년 여름에 오하 이오 주 오와타 군(Owatta, Ohio, USA)에서 $\mathrm{MC}$ 가 검출되 어 수도수 음용 금지의 경고를 내렸다. 남조 독소는 상수도 수원지의 오염뿐만 아니라 야생생물에 대한 중대한 피해가 예상된다. 아리아케 해의 이사하야 만에 대한 간척사업에 의한 조정지가 완성되고 수년 후부터 거의 매년 여름 녹조 현상이 발생하며, 그 남조가 바다로 흘러 해저동물에 독소 가 축적 된다고 사료된다. 북미에서도 하천에서 연안으로 남조가 떠내려가 어패류의 중장선에 남조 독소가 검출되어 식품위생상의 문제가 화제가 되는 한편, 어패류의 중장선 조 직이 남조 독소에 의해 손상된다는 보고도 있으며, 수생동 물을 보호 하는 측면에서도 주의를 기울일 필요가 있다.

\section{Acknowledgement}

This research was financially supported by Korea Institute of Civil Engineering and Building Technology (KICT), project No. 2015-0123.

\section{KSEE}

\section{References}

1. Dawson, R. M., "The toxicology of microcystins," Toxicon, 36(7), 953 962(1998).

2. Carmichael, W., "Health effects of toxin-producing cyanobac- teria: The CyanoHABs," Hum. Ecol. Risk Assess.: An Int. J., 7(5), 1393 1407(2001).

3. Harada, K., Ohtani, I., Iwamoto, K., Suzuki, M., Watanabe, M. F., Watanabe, M. and Terao, K., "Isolation of cylindrospermopsin from a cyanobacterium Umezakia natans and its screening method," Toxicon, 32(1), 73 84(1994).

4. Matsunaga, H., Harada, K., Senma, M., Ito, Y., Yasuda, N., Ushida, S. and Kimura, Y., "Possible cause of unnatural mass death of wild birds in a pond in Nishinomiya, Japan: Sudden appearance of toxic cyanobacteria," Nat. Toxins, 7 (2), 81 84(1999).

5. Nakamura, K., Watanabe, K., Ishikawa, K., Kumagai, M., Miyabara, Y., Inuzuka, R., Yokota, K., Oguma, K. and Park, H., "Accumulation of microcystin-LR in dead domestic duck at Iso harbor, Lake Biwa, Japan (in Japanese)," Japanese $J$. Omithol., 62(2), 153 165(2013).

6. Carmichael, W., "Cyanobacteria secondary metabolites-the cyanotoxins,” J. Appl. Microbiol., 72(6), 445 459(1992).

7. MacKintosh, C., Beattie, K. A., Klumpp, S., Cohen, P. and Codd, G. A., "Cyanobacterial microcystin-LR is a potent and specific inhibitor of protein phosphatases 1 and $2 \mathrm{~A}$ from both mammals and higher plants," FEBS Lett., 264(2), 187 192(1990).

8. Kondo, F., Ikai, Y., Oka, H., Okumura, M., Ishikawa, N., Harada, K., Matsuura, K., Murata, H. and Suzuki, M., "Formation, Characterization, and Toxicity of the Glutathione and Cysteine Conjugates of Toxic Heptapeptide Microcystins," Chem. Res. Toxicol., 5(5), 591 596(1992).

9. Park, H., "Studies on the Toxins Produecd by Blue-Green Algae (in Japanese)," J. JPN Soc. Wat. Environ., 37(5), 169 174 (2014).

10. Xie, L., Hanyub, T., Futatsugi, N., Komatsuc, M., Steinmand, A. D. and Park H., "Inhibitory effect of naringin on microcystin-LR uptake in the freshwater snail Sinotaia histrica," Environ. Toxicol. Phar., 38, 430 437(2014).

11. Harada, K., Nagai, H., Kimura, Y., Suzuki, M., Park, H., Watanabe, M. F., Luukkainen, R., Sivonen, K. and Carmichael, W. W., "Liquid chromatography/mass spectrometric detection of anatoxin-a, a neurotoxin from cyanobacteria," Tetrahedron, 49(41), 9251 9260(1993).

12. Park, H., Watanabe, M. F., Harada, K., Nagai, H., Suzuki, M., Watanabe, M. and Hayashi, H., "Hepatotoxin (microcystin) and neurotoxin (anatoxin-a) contained in natural blooms and strains of cyanobacteria from Japanese freshwaters," Nat. Toxins, 1(6), 353 360(1993).

13. Swanson, K. L., Allen, C. N., Aronstam, R. S., Rapoport, H. and Albuquerque, E. X., "Molecular mechanisms of the potent and stereospecific nicotinic receptor agonist (+)-anatoxin-a," Mol. Pharmacol., 29(3), 250 257(1986).

14. Falconer, I. R. and Humpage A. R., "Cyanobacterial (bluegreen algal) toxins in water supplies: Cylindrospermopsins," Environ. Toxicol., 21(4), 299 304(2006).

15. Hawkins, P. R., Runnegar, M. T. C., Jackson, A. R. and Falconer, I. R., "Severe hepatotoxicity caused by the tropical cyanobacterium (blue-green alga) Cylindrospermopsis raci- 
borskii (Woloszynska) Seenaya and Subba Raju isolated from a domestic supply reservoir," Appl. Environ. Microbiol., 50 (5), 1292 1295(1985).

16. Banker, R., Carmeli, S., Hadas, O., Teltsch, B., Porat, R. and Sukenik, A., "Identification of cylindrospermopsin in the cyanobacterium Aphanizomenon ovalisporum (Cyanophyceae) isolated from lake Kinneret, Israel," J. Phycol., 33(4), 613 616(1997).

17. Schembri, M. A., Neilan, B. A. and Saint, C. P., "Dentification of genes implicated in toxin production in the cyanobacterium Cylindrospermopsis raciborskii," Environ. Toxicol., 16(5), 413 421(2001).

18. Li, R., Carmichael, W. W., Brittain, S., Eaglesham, G. K., Shaw, G. R., Yongding, L. and Watanabe, M. M., "First report of the cyanotoxins cylindrospermopsin and deoxycylindrospermopsin from Raphidiopsis curvata (cyanobacteria)," J. Phycol., 37(6), 1121 1126(2001).

19. Larson, D., Ahlgren, G. and Willén, "Bioaccumulation of microcystins in the food web: a field study of four Swedish lakes," Inland Waters, 4(1), 91 104(2014).

20. Katagami, Y., Tanaka, T., Honma, T., Yokoyama, A. and Park, H., "Bioaccumulation of a cyanobacterial toxin, microcystin, on Stenopsyche marmorata and the ecological implications for its impact on the ecosystem of the Tenryu River, Japan (in Japanese)," Japanese J. Limnol., 65(1), 1 12 (2004).

21. Park, H., "Dynamics and bioaccumulation of microcystin in aquatic ecosystem (in Japanese)," Kaiyo Monthly, 37(5), 325 334(2005).

22. Miller, M. A., Kudela, R. M., Mekebri, A., Crane, D., Oates, S. C., Tinker, M. T., Staedler, M., Miller, W. A., ToyChoutka, S., Dominik, C., Hardin, D., Langlois, G., Murray, M., Ward, K. and Jessup, D. A., "Evidence for a novel marine harmful algal bloom: cyanotoxin (microcystin) transfer from land to sea otters," PLoS One 5(9): e12576. Doi:10. 1371/journal.pone.0012576, (2010).

23. Takahashi, T., Umehara, A. and Tsutsumi, H., "Diffusion of microcystins (cyanobacteria hepatotoxins) from the reservoir of Isahaya Bay, Japan, into the marine and surrounding ecosystems as a result of large-scale drainage," Mar. Pollut. Bull., 89(1-2), 250 258(2014).

24. Lambert, T. W., Holmes, C. F. B. and Hrudey, S. E., “Adsorption of microcystin-LR by activated carbon and removal in full scale water treatment," Water Res., 30(6), 1411 1422 (1996).

25. Tsuji, K., Watanuki, T., Kondo, F., Watanabe, M. F., Nakazawa, H., Suzuki, M., Uchida, H. and Harada, K., "Stability of Microcystins from cyanobacteria-iv. Effect of chlorination on decomposition," Toxicon, 35(7), 1033 1041(1997).

26. Rositano, J., Nicholson, B. C. and Pieronne, P., "Destruction of cyanobacterial toxins by ozone," Ozone: Sci. Eng., 20(3), 223 238(1998).

27. Tsuji, K., Naito, S., Kondo, F., Ishikawa, N., Watanabe, M. F., Suzuki, M. and Harada, K., "Stability of microcystins from cyanobacteria: effect of light on decomposition and iso- merization," Environ. Sci. Technol., 28(1), 173 177(1994).

28. Jeon, B., Han, J., Makino, K. and Park, H., "Degradation of microcystin and possible phosphorus removal mechanism by electrochemical treatment," Environ. Eng. Sci., 31(9), 525 531(2014).

29. Lawton, L. A. and Robertson, P. K. J., "Physico-chemical treatment methods for the removal of microcystins (cyanobacterial hepatotoxins) from potable waters," Chem. Soc. Rev., 28, 217 224(1999).

30. Han, J., Jeon B., Futatsuki, N. and Park, H., "The effect of alum coagulation for in-lake treatment of toxic Microcystis and other cyanobacteria related organisms in microcosm experiments," Ecotox. Environ. Safe., 96, 17 23(2013).

31. Bourne, D. G., Jones, G. J., Blakerley, R. L., Jones, A., Negri, A. P. and Riddles, P., "Enzymatic pathway for the bacterial degradation of the cyanobacterial cyclic peptide toxin microcystin LR," Appl. Environ. Microbiol., 62(11), 4086 4094 (1996).

32. Park, H., Sasaki, Y., Maruyama, T., Yanagisawa, E., Hiraishi, A. and Kato, K., "Degradation of the cyanobacterial hepatotoxin microcystin by a new bacterium isolated from a hypertrophic lake," Environ. Toxicol., 16, 337 343(2001).

33. Maruyama, T., Park, H., Ozawa, K., Tanaka, Y., Sumino, T., Hamana, K., Hiraishi, A. and Kato, K., "Sphingosinicella microcystinivorans gen. nov., sp. nov., a microcystin-degrading bacterium," Int. J. Syst. Evol. Micro., 56, 58 59(2006).

34. Ho, L., Hoefel, D., Saint, C. P. and Newcombe, G., "Isolation and identification of a novel microcystin-degrading bacterium from a biological sand filter," Water Res., 41(20), 4685 4695 (2007).

35. Ho, L., Tang, T., Monis, P. T. and Hoefel, D., "Biodegradation of multiple cyanobacterial metabolites in drinking water supplies," Chemosphere, 87(10), 1149 1154(2012).

36. Zhang, M., Pan, G. and Yan, H., "Microbial biodegradation of microcystin-RR by bacterium Sphingopyxis sp. USTB-05," J. Environ. Sci., 22(2), 168 175(2010).

37. Yan, H., Wang, H., Wang, J., Yin, C., Ma, S., Liu, X. and Yin, X., "Cloning and expression of the first gene for biodegrading microcystin LR by Sphingopyxis sp. USTB-05," J. Environ. Sci., 24(10), 1816 1822(2012).

38. Alamri, S. A., "Biodegradation of microcystin by a new Bacillus sp. isolated from a Saudi freshwater lake," Afr. J. Biotechnol., 9(39), 6552 6559(2010).

39. Chen, J., Hu, L., Zhou, W., Yan, S., Yang, J., Xue, Y. and Shi, Z., "Degradation of microcystin-LR and RR by a Stenotrophomonas sp. strain EMS isolated from Lake Taihu, China," Int. J. Mol. Sci., 11(3), 896 911(2010).

40. Jiang, Y., Shao, J., Wu, X., Xu, Y. and Li, R., "Active and silent members in the $m l r$ gene cluster of a microcystindegrading bacterium isolated from Lake Taihu, China," FEMS Microbiol. Lett., 322(2), 108 114(2011).

41. Takenaka, S. and Watanabe, M. F., "Microcystin LR degradation by Pseudomonas aeruginosa alkaline protease," Chemosphere, 34(4), 749 757(1997).

42. Zhang, M., Yan, H. and Pan, G., "Microbial degradation of 
microcystin-LR by Ralstonia solanacearum," Environ. Technol., 32(15), 1779 1787(2011).

43. Rapala, J., Berg, K.A., Lyra, C., Niemi, R. M., Manz, W., Suomalainen, S., Paulin, L. and Lahti, K., "Paucibacter toxinivorans gen. nov., sp. nov., a bacterium that degrades cyclic cyanobacterial hepatotoxins microcystins and nodularin.," Int. J. Syst. Evol. Micro., 55, 1563 1568(2005).

44. Lemes, G. A. F., Kersanach, R., Pinto, L. S., Dellagostin, O. A., Yunes, J. and Matthiensen, A., "Biodegradation of microcystins by aquatic Burkholderia sp. from a South Brazilian coastal lagoon.," Ecotox. Environ. Safe., 69(3), 358 365(2008).

45. Hu, L., Yang, J., Zhou, W., Yin, Y., Chen, J. and Shi, Z., "Isolation of a Methylobacillus sp. that degrades microcystin toxins associated with cyanobacteria," New Biotechnol., 26 (3-4), 205 211(2009).
46. Jia, Y., Du, J., Song, F., Zhao, G. and Tian, X., "A fungus capable of degrading microcystin-LR in the algal culture of Microcystis aeruginosa PCC7806," Appl. Biochem. Biotechnol., 166, 987 996(2012)

47. Dziga, D., Wasylewski, M., Wladyka, B., Nybom, S. and Meriluoto, J., "Microbial degradation of microcystins," Chem. Res. Toxicol., 26(6), 841 852(2013).

48. Park, H., "Dynamics of the microcystin in aquatic ecosystem (in Japanese)," Bullet. Plankton Soc. Jap., 55(1), 58 62(2008).

49. Chorus, I. and Bartram, J., "Toxic cyanobacteria in water: A guide to their public health consequences, monitoring and management," WHO(1999).

50. WHO, "Guidelines for drinking water quality," 2nd ed. Addendum to Volume 2, Health criteria and other supporting information, Geneva, Switzerland(1998). 